\title{
Description of Phradonoma blabolili sp. n. (Coleoptera, Dermestidae, Megatominae), with notes on the dermestid beetles from Angola
}

\author{
Jiř́ Háva ${ }^{1, \dagger}$, Tomáš Lackner ${ }^{1, \ddagger}$, Jana Mazancová2,\$ \\ I Department of Forest Protection and Entomology, Faculty of Forestry and Wood Sciences, Czech University \\ of Life Sciences, Kamýcká 129, CZ-165 21, Prague 6 - Suchdol, Czech Republic 2 Institute for Tropics and \\ Subtropics, Czech University of Life Sciences, Kamýcká 129, CZ-165 21, Prague 6 - Suchdol, Czech Republic \\ † urn:lsid:zoobank.org:author:71D662DB-2F3D-4418-98B6-E1DF82895AC5 \\ † urn:lsid:zoobank.org:author:E1DA422B-F56F-4253-A55D-481479D933B8 \\ § urn:lsid:zoobank.org:author:BD064E2E-23B7-4820-9A64-068BE643C26D \\ Corresponding author: Tomás Lackner (tomaslackner@me.com)
}

Academic editor: P. Bouchard | Received 20 February 2012 | Accepted 5 April 2013 | Published 19 April 2013

urn:lsid:zoobank.org:pub:34B6B8DD-1455-472A-8C3D-DF2137560E76

Citation: Háva J, Lackner T, Mazancová J (2013) Description of Phradonoma blabolili sp. n. (Coleoptera, Dermestidae, Megatominae), with notes on the dermestid beetles from Angola. ZooKeys 293: 65-76. doi: 10.3897/zookeys.293.4891

\begin{abstract}
Phradonoma blabolili sp. n. from Angola is described and illustrated. Key to the Afrotropical "Phradonoma nobile species group" to which the newly described species belongs, as well as key to genera of dermestid beetles occurring in Angola is given. List of all species of Dermestidae known to occur in Angola hitherto is provided.
\end{abstract}

\section{Keywords}

Taxonomy, new species, Coleoptera, Dermestidae, Phradonoma, Angola

\section{Introduction}

The family Dermestidae (Coleoptera: Bostrichoidea) contains about 1440 species and subspecies worldwide (Háva 2003a, Háva and Solervicens 2012). Its members are "mainly scavengers on dried proteinaceous material and are of economic importance because the family includes species that are pests of stored products or natural-history enemies" (Lawrence and Ślipiński 2005). Despite their species richness, only 14 species have been

Copyright Jiři Háva et al. This is an open access article distributed under the terms of the Creative Commons Attribution License 3.0 (CC-BY), which permits unrestricted use, distribution, and reproduction in any medium, provided the original author and source are credited. 
reported from Angola hitherto (Erichson 1843, Ferreira 1965, Háva 2003a,b, Kadej 2006, 2010, Mroczkowski 1968, Pacavira et al. 2006, Pic 1931, 1937). This doubtlessly small number is perhaps largely due to the 27 years of Angolan civil war (1975-2002) which was a serious impediment to entomological research; the actual number of species is undoubtedly much higher. After the end of the conflict, and especially in the recent years, specialists carrying out entomological research seem to be returning to Angola. The genus Phradonoma Jacquelin du Val, 1859 is distributed largely in Palaearctic and Afrotropical regions and one species has been introduced into the U.S.A. In this contribution to the taxonomy of Angolan Dermestidae (Coleoptera) we describe one new species of Phradonoma and provide a summary of the dermestid taxa occurring there.

\section{Material and methods}

The type specimen of this new species has been collected using flight intercept trap in open savannah near Catabola, in the central Angolan province of Bié, in altitude 1300 $\mathrm{m}$. The FIT trap has been placed near a small pond, and cow dung, rotting bananas as well as rotting fish were all used to attract insects. The attractants were placed in small plastic containers around the trap. When removing the male terminalia from the specimen, the entire abdomen was first severed from the rest of the body, subsequently macerated in $\mathrm{KOH}$ heated up to $90^{\circ} \mathrm{C}$ for a short while, cleared in $96 \%$ ethanol and thence the male genitalia was removed from the cleared abdomen. The habitus photographs of $P$. blabolili was taken by macroscope Leica 216 APO. The dissected male genitalia was macerated in $10 \%$ solution of $\mathrm{KOH}$ heated up to $90{ }^{\circ} \mathrm{C}$ for a few minutes, cleared in Xylene and transferred into glycerin in small glass dish where it was observed. The photograph of the male genitalia has been taken with Olympus BX 41 camera. The map on Fig. 5 depicting the type locality of $P$. blabolili was downloaded from the Internet and subsequently re-drawn using Adobe Illustrator CS4. The type specimen is deposited in the collection of the senior author (JHAC).

Standard measurements have been made according to Háva (2006) and are as follows:

BL Body length - linear distance measured from anterior margin of pronotum to apex of elytra;

BW Body width - measured between two anterolateral humeral calli;

PL Pronotum length - measured from the top of the anterior margin to scutellum;

PW Pronotum width - measured between the two posterior angles of pronotum;

EL Elytral length- linear distance measured from shoulder to apex of elytron.

\section{Abbreviation}

JHAC Private Entomological Laboratory \& Collection, Únětice u Prahy, Praguewest, Czech Republic 


\section{Results}

\section{Subfamily Megatominae Leach, 1815 \\ Tribe Megatomini Leach, 1815}

\section{Phradonoma blabolili sp. $\mathrm{n}$.}

urn:Isid:zoobank.org:act:93246F10-2B76-4573-9771-C6F3C84E7538

http://species-id.net/wiki/Phradonoma_blabolili

Figs $1-5$

Type material. Holotype, male, with printed label "Angola, Bié province, Catabola env., 15-27.11.2012, FIT trap, T. Lackner lgt.” (JHAC).

Description. Male. Body measurements: BL $2.20 \mathrm{~mm}$; BW $1.30 \mathrm{~mm}$; PL 0.60 mm; PW $1.10 \mathrm{~mm}$; EL $1.70 \mathrm{~mm}$. Body (Fig. 1) dark brown and black, elongate oval. Head entirely black, coarsely punctuate, with decumbent light brown setae; maxillary palpi dark brown. Eyes large, with short microscopic setae. Antennae with 11 antennomeres, antennal club consisting of 3 antennomeres; antennomeres I-VIII brown, antennomeres IX-XI black, furnished with short setae (Fig. 2). Frons with small dark brown ocellus. Pronotum entirely black, shiny, sparsely and finely punctuate, with dark and semi-erect setae medially, white setae increase in number towards the lateral margins, posterior edges and in ante-scutellar area; lateral pronotal margins not visible from above. Scutellum small, black and triangular, asetose and impunctate.

Elytra black in anterior half, dark brown on posterior half, sparsely and coarsely punctuate; sparsely covered with semi-erect dark setae. Each elytron bears four transverse fasciae formed by intermixed white and yellow setae: the first situated near scutellum; second present anteriorly, reaching elytral suture; third fascia situated sub-medially reaching elytral suture; and the fourth fascia situated sub-apically, reaching elytral suture. Elytral epipleuron short, black, with dark setae.

Metaventrite finely punctuate with white, short, recumbent setae. Mesoventrite coarsely punctuate laterally, medially finely punctuate, and covered by white, short, recumbent setae.

All abdominal ventrites black, covered by short, white, recumbent setae; first abdominal ventrite with distinct oblique discal striae.

Legs. Tibiae and tarsi brown, femora anteriorly darkened and sparsely covered with fine white setae. Anterior tibiae with black spines along shaft.

Male genitalia. Parameres widely 'open' connected anteriorly by a 'bridge', parameres apically with pseudopores and short setae; basal piece strongly sclerotized; penis apically with downward pointing 'hook'. Penis has been slightly damaged during the manipulation with the aedeagus and therefore we decided to show the photograph as well as the drawing of the aedeagus depicting a reconstructed penis. (Figs 3-4).

Female unknown.

Differential diagnosis. This new species belongs to the genus Phradonoma Jacquelin du Val, 1859, and can be placed into the "P. nobile species group" (sensu Háva 2006; 


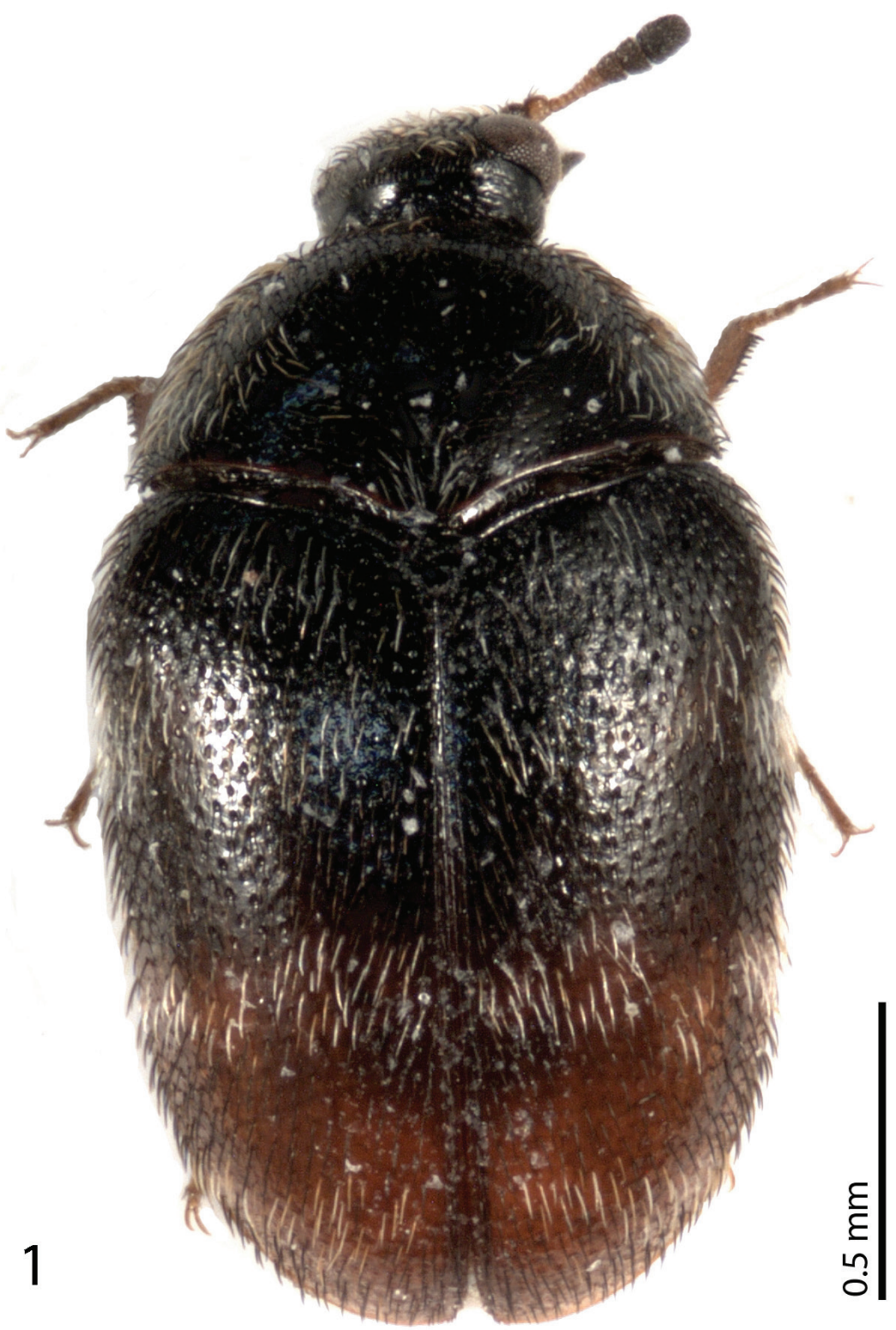

Figure I. Phradonoma blabolili sp. n., habitus, dorsal view.

see also below). Phradonoma blabolili sp. n. is visually most similar to P. cornelli Háva \& Hermann, 2009 and can be differentiated from it by the characters given in the key.

Distribution. Known only from the vicinity of Catabola, Bié province, central Angola (Fig. 5).

Etymology. Patronymic, dedicated to Martin Blabolil, (Kuito, Angola) who has been instrumental in providing all kinds of help during the visit of Tomáš Lackner in Angola. 


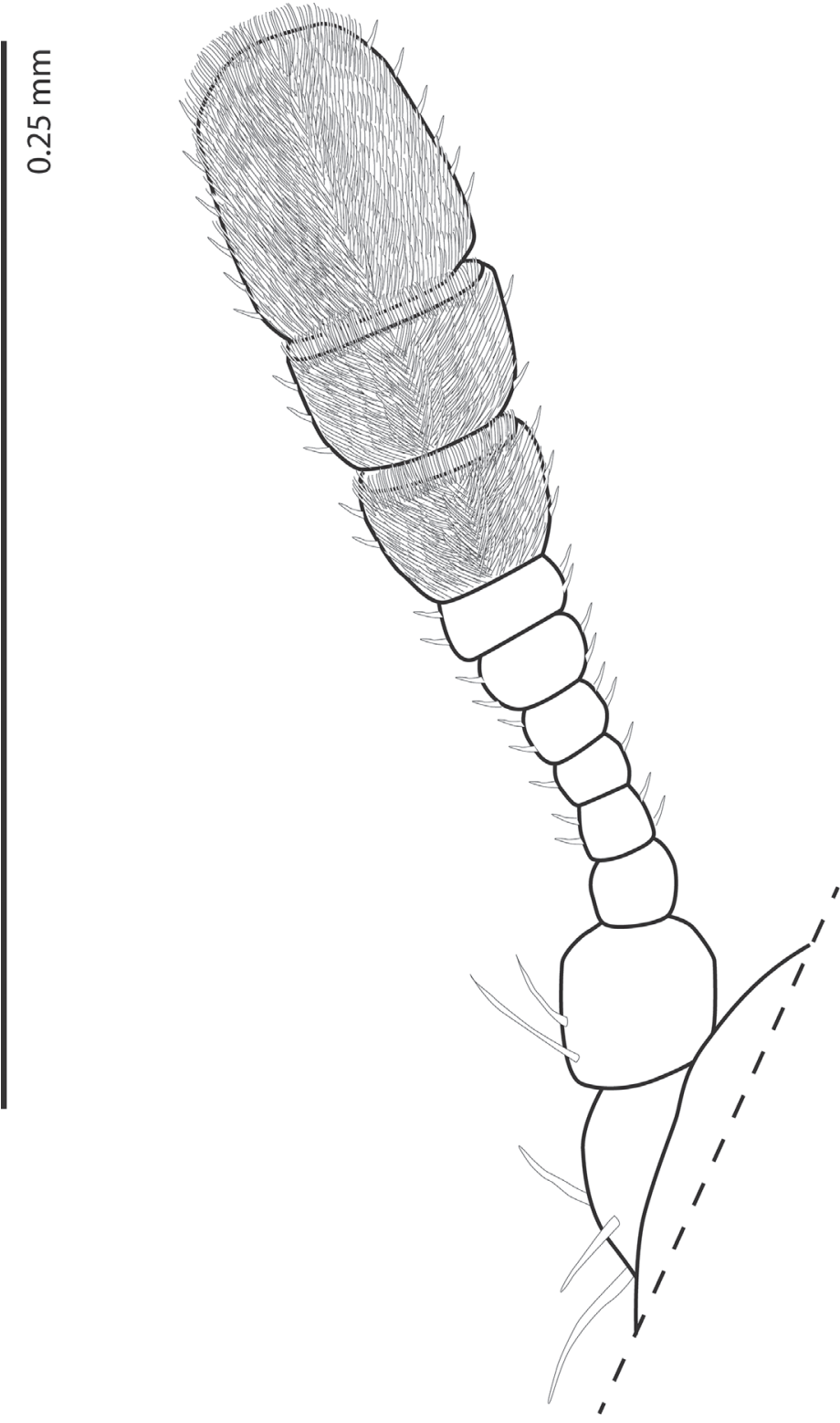

Figure 2. Phradonoma blabolili sp. n., antenna, dorsal view. 


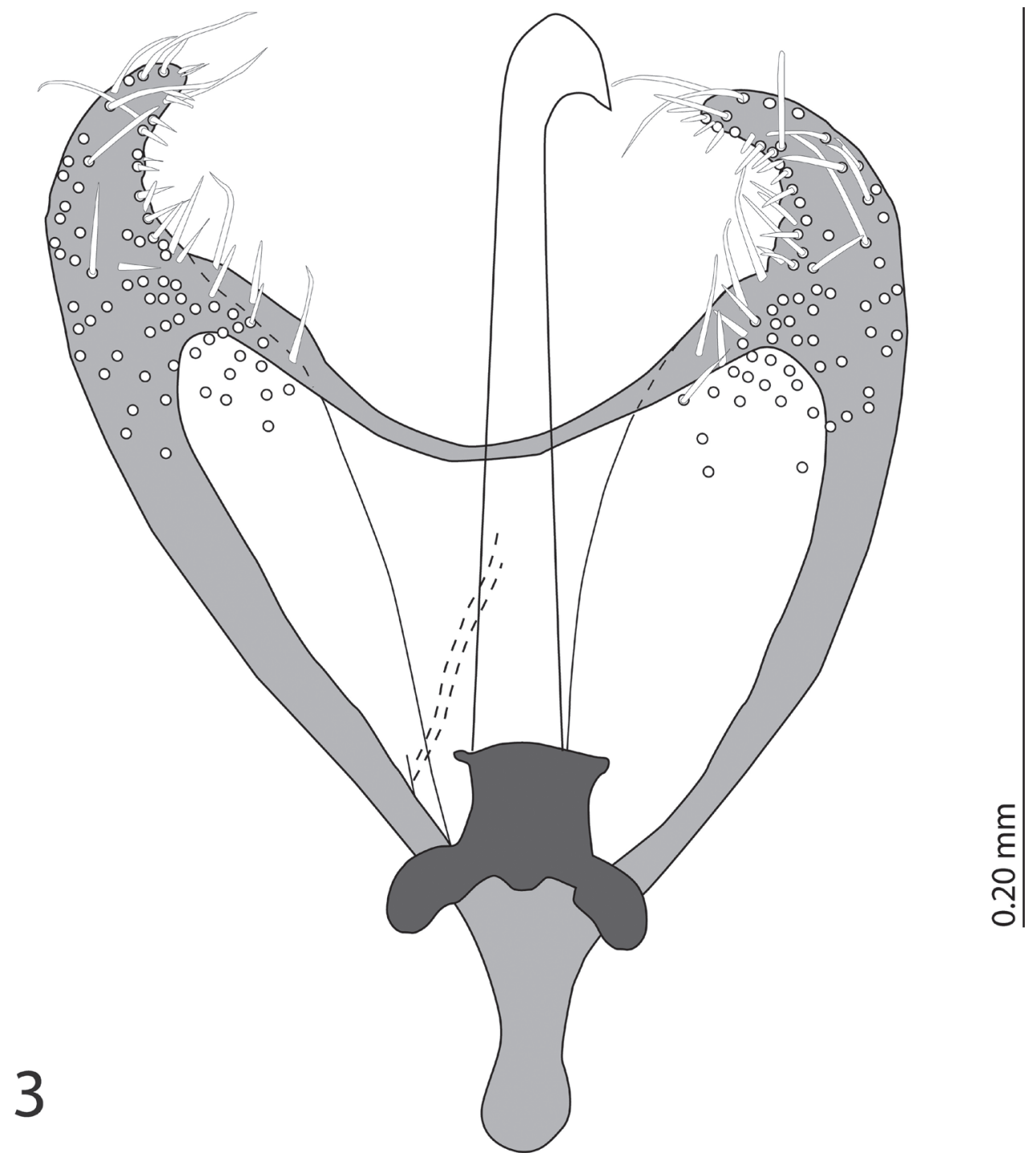

Figure 3. Phradonoma blabolili sp. n., aedeagus, dorsal view, showing the reconstructed penis. 


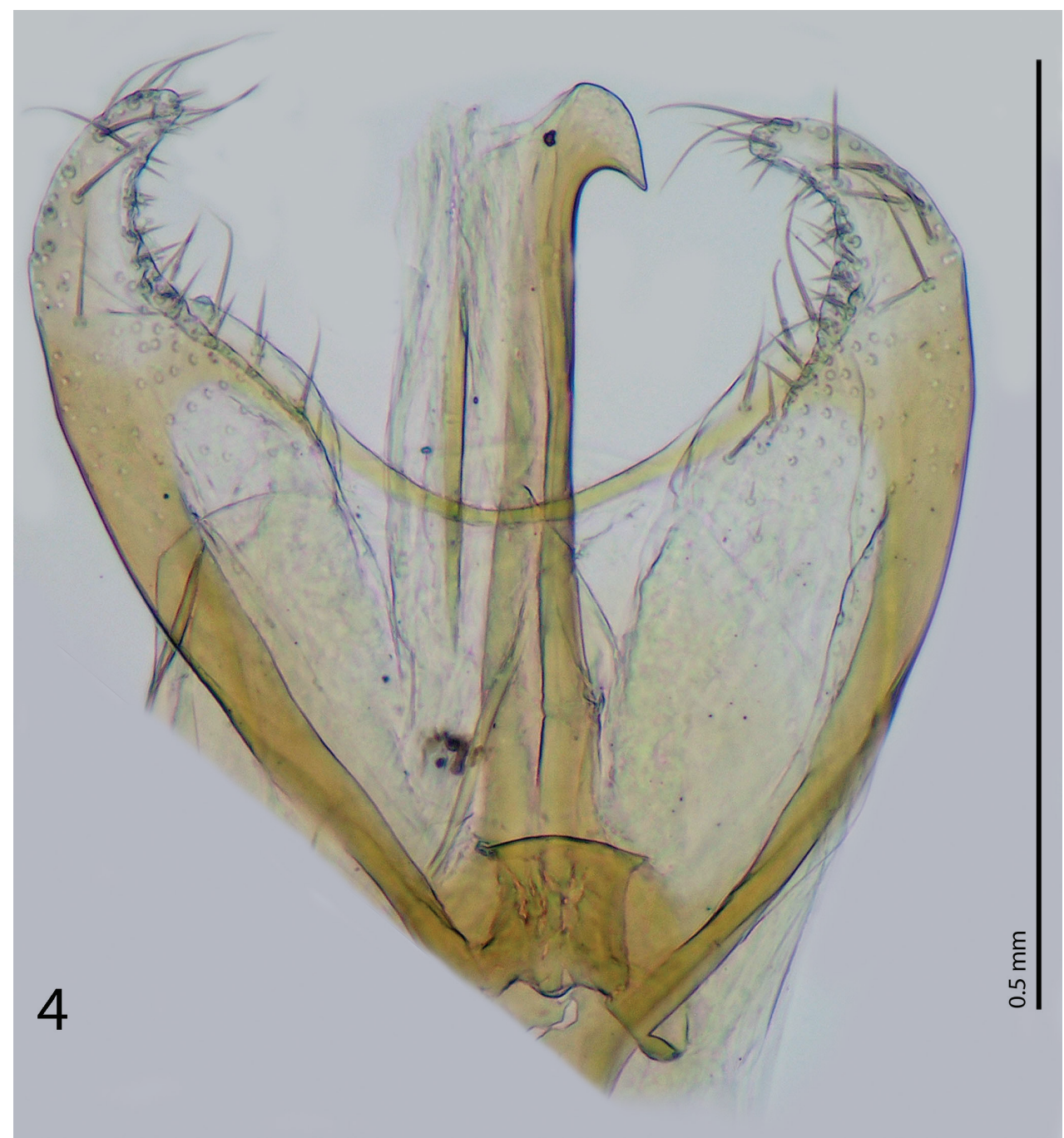

Figure 4. Phradonoma blabolili sp. n., aedeagus, depicting the damaged penis. 


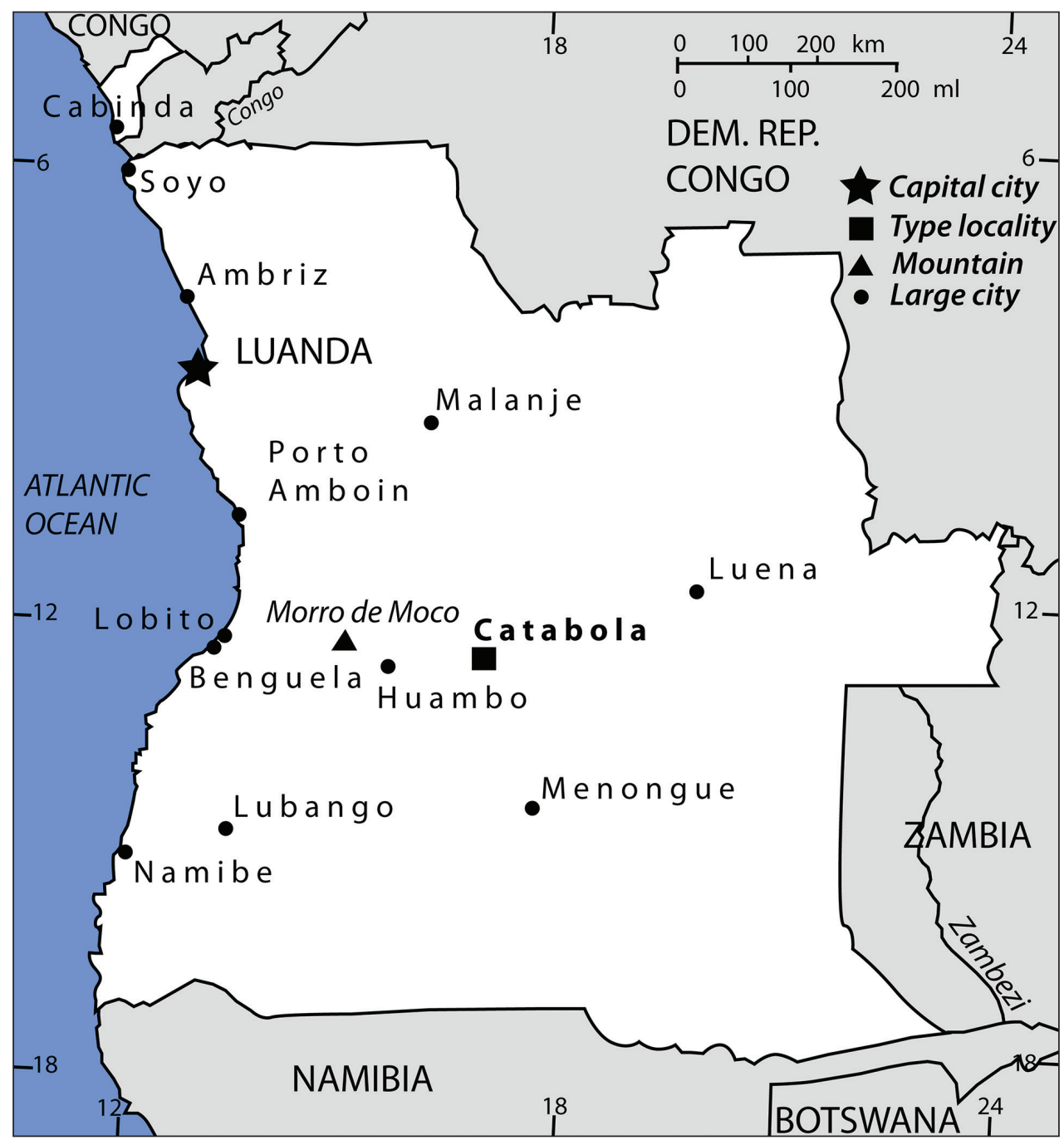

Figure 5. Map of Angola showing the type locality of Phradonoma blabolili sp. n.

\section{Key to the Afrotropical "Phradonoma nobile species group"}

"Phradnonoma nobile species group" of the genus Phradonoma can be defined by the combination of the following putative synapomorphies: cuticle bicolored, dorsal body surface with bi- or tri-colored setae and antennal club consisting from three antennomeres (see also Háva 2006).

1 Body form narrow, parallel, elytra without white setae, black with orange apex; antennal club with 5 antennomeres (Kenya, Namibia, Tanzania) ........ P. babaulti (Pic, 1921) 
- $\quad$ Body form oval, elytra with brown and white or grey setae, antennal club with 3 antennomeres 2

Berminal antennal antennomere triangular; elytra brownish-black except for three (sometimes only two) red, transverse bands and small circular spots; (Cyprus, England (intr.), Greece, Portugal, Spain, Algeria, Egypt, Eritrea, Libya, Morocco, Namibia, Nigeria, South Africa, South Sudan, Sudan, Tanzania, Tunisia, Zimbabwe, Afghanistan, „Caucasus“, India: Madhya Pradesh, Rajasthan, Uttar Pradesh, Iran, Iraq, Israel, Jordan, Pakistan, Qatar, Saudi Arabia, Syria, Tajikistan, Turkmenistan, United Arab Emirates, Uzbekistan, USA: Arizona (intr.)) P. nobile (Reitter, 1881)

Terminal antennal antennomere oval Elytra with light fasciae of setae and apical spot .................................5

Elytra with isolated light spots of setae............................................. 7 Elytra with one orange transverse fasciae, small median orange patches and orange apical spot all covered by white setae; body length $2.30-2.70 \mathrm{~mm}$; antennal club with 3 antennomeres (Botswana, Congo, Namibia, South Africa, Tanzania, Zambia, Zimbabwe) P. eximium (Arrow, 1915) Elytra dark brown or black and dark brown without median, orange or brown patches

Elytra dark brown, each elytron covered by slightly erected dark setae with three or four fasciae and small apical spot from light brown and white setae; body length 2.10-2.60 mm; antennal club with 3 antennomeres (Cameroon)..... P. cornelli Háva \& Herrmann, 2009 Elytra black in anterior half, dark brown posteriorly, each elytron with four distinct transverse fasciae from grey setae; body length $2.20 \mathrm{~mm}$; antennal club with 3 antennomeres (Angola: Bié province) P. blabolili sp. n. Elytra with isolated light spots of setae....

Elytra black, without red, orange or brown parts. Body length 2.60-2.70 $\mathrm{mm}$; antennal club with 3 antennomeres; each elytron with very small isolated 13-14 white spots (Kenya, Madagascar).

P. albonotatum (Pic, 1927)

- $\quad$ Elytra with red, orange or brown parts.

9 Pronotum with 5 isolated white patches, two in lateral parts, two medially and one near scutellum; body length $2.30-3.30 \mathrm{~mm}$; antennal club with 3 antennomeres; elytra black with orange-brown apical part and with small white spots (Botswana, South Africa).

P. borowieci Háva \& Kadej, 2006

- $\quad$ Pronotum with two lateral white patches

10 Elytra near scutellum coarsely punctured with small humeral bump; body length $2.80 \mathrm{~mm}$; antennal club with 3 antennomeres; elytra black, each elytron with 12 small, distinct spots of white setae on three or four very blurred fasciae and an apical spot (Cameroon). 
- $\quad$ Elytra near scutellum finely punctured with very large humeral bump; body length $2.40-3.20 \mathrm{~mm}$; antennal club with 3 antennomeres; elytra black with orange apex, each elytron intermixed in brown setae with small patches of white setae (Namibia)

P. namibicum Háva, 2005

\section{Key to genera of Dermestidae hitherto known to occur in Angola}

1 Head without frontal ocellus subfamily Dermestinae, genus Dermestes, 2

- $\quad$ head with frontal ocellus 3

2 visible abdominal sternites with white and black pubescence . subgenus Dermestinus Zhantiev, 1967

- visible abdominal sternites with concolorous pubescence subgenus Dermestes Linnaeus, 1758

3 prosternum not forming a "collar"; mouthparts free subfamily Attageninae, genus Attagenus Latreille, 1802 - $\quad$ prosternum forming a "collar" under which mouthparts fit when the head is retracted subfamily Megatominae, 4 dorsal and ventral surfaces covered by flat scales genus Anthrenus, 5 dorsal and ventral surfaces covered by pubescence. antenna with 11 antennomeres antenna with 10 antennomeres ........ subgenus Anthrenodes Chobaut, 1898 eyes with median margin broadly and deeply emarginate at about anterior

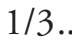
subgenus Anthrenus Geoffroy, 1762

- $\quad$ eyes with median margins complete. subgenus Nathrenus Casey, 1900 anterior tibiae with spines along shaft; antennal club with 3 antennomeres... genus Phradonoma Jacquelin du Val, 1859 antennal club with 2 antennomeres, terminal antennomere of male big, flat and slightly vaulted genus Orphinus Motschulsky, 1858

- $\quad$ antennal club with 3-8 antennomeres genus Trogoderma Dejean, 1821

\section{List of the dermestid beetles reported from Angola so far:}

Subfamily Dermestinae Latreille, 1804

Tribe Dermestini Latreille, 1804

Dermestes (Dermestes) ater DeGeer, 1774

= Dermestes cadaverinus Fabricius, 1775

= Dermestes domesticus Germar, 1824

= Dermestes cinereus Motschulsky, 1848 
Dermestes (Dermestes) lardarius Linnaeus, 1758

Dermestes (Dermestinus) maculatus DeGeer, 1774

= Dermestes vulpinus Fabricius, 1781

$=$ Dermestes senex Germar, 1824

= Dermestes lupinus Eschscholtz in Mannerheim, 1843

Subfamily Attageninae Laporte, 1840

Tribe Attagenini Laporte, 1840

Attagenus donckieri Pic, 1916

Attagenus fasciatus (Thunberg, 1795)

= Anthrenus gloriosae Fabricius, 1798

Attagenus hargreavesi Pic, 1935

Attagenus havai Kadej, 2006

Attagenus vestitus Klug, 1855

= Attagenus rhodesianus Pic, 1927

Subfamily Megatominae Leach, 1815

Tribe Anthrenini Gistel, 1848

Anthrenus (Anthrenodes) endroedyi Háva, 2003b

Anthrenus (Anthrenus) flavipes flavipes LeConte, 1854

Anthrenus (Nathrenus) maltzi Kadej, 2010

Anthrenus (Nathrenus) verbasci (Linnaeus, 1767)

Tribe Megatomini Leach, 1815

Orphinus (Orphinus) aethiops Arrow, 1915

Orphinus (Orphinus) incognitus Háva, 2003b

Phradonoma blabolili sp. n.

Trogoderma granarium Everts, 1898

\section{Acknowledgements}

This research was supported by the Internal Grant Agency (IGA n.20124364) Faculty of Forestry and Wood Sciences, Czech University of Life Sciences Prague. We would like to thank Petr Baňař (Brno, Czech Republic) for the help with the imaging of this new species. Wife of the second author (T.L.) Pepina Artimová has drawn the map used in this paper using Adobe Illustrator CS4 and helped with drawing the aedeagus of P. blabolili and we would like to express our sincere gratitude to her for it. We thank Adam Ślipiński (CSIRO, Canberra, Australia) for the help with the genitalic morphology as well as two anonymous reviewers for the improved quality of our paper. 


\section{References}

Erichson WF (1843) Beiträg zur Insecten-Fauna von Angola, in besonderer Beziehung zur geographischen Verbreitung der Insecten in Afrika. Archiv für Naturgeschichte, Berlin 9: 199-267.

Ferreira MC (1965) Catalogo dos Coleopteros de Angola. Revue Entomologique Mocambique 8: 417-1317.

Háva J (2003a) World Catalogue of the Dermestidae (Coleoptera). Studie a Zprávy Oblastního Muzea Praha-východ v Brandýse nad Labem a Staré Boleslavi, Supplementum 1: 1-196.

Háva J (2003b) Two new species of the genus Orphinus from Afrotropical region (Coleoptera, Dermestidae, Megatominae). Lambillionea 103: 146-148.

Háva J (2006) Notes on the genus Phradonoma from the Middle East with description of nine new species (Coleoptera: Dermestidae: Megatominae). Genus 17: 79-94.

Háva J, Solervicens J (2012) Contribution to the knowledge of Dermestidae (Coleoptera) from Chile. Contribución al conocimiento de los Dermestidae (Coleoptera) de Chile. Revista Chilena de Entomología 37: 17-21.

Kadej M (2006) Description of a new Attagenus species from Afrotropical region (Coleoptera, Dermestidae). Studies and Reports of District Museum Prague-east, Taxonomical Series 2: 81-84.

Kadej M (2010) A new species of Anthrenus Geoffroy, 1762 (Coleoptera: Dermestidae: Megatominae) from Angola. Annales Zoologici 60: 547-551. doi: 10.3161/000345410X550391

Lawrence JF, Slipinski A (2005) Three new genera of Indo-Australian Dermestidae (Coleoptera) and their phylogenetic significance. Invertebrate Systematics 19: 231-261. doi: 10.1071/IS04033

Mroczkowski M (1968) Distribution of the Dermestidae (Coleoptera) of the world with a catalogue of all known species. Annales Zoologici 26: 15-191.

Pacavira R, Mata O, Manuel A, Pereira AP \& Mexia A (2006) Detection of stored products pests by pheromone traps in seven warehouse in Luanda/Angola. General Session on Stored Grain Protection. $9^{\text {th }}$ International Working Conference on Stored Product Protection. Sao Paulo, 1157-1165.

Pic M (1931) Coléoptères (Clavicornes, Clérides, Malacodermes, Hétéromeres, Bruchides, Phytophages) d'Angola. Revue Suisse de Zoology 38: 419-427.

Pic M (1937) Coléoptères (Clavicornes, Malacodermes, Hétéromeres e. p. et Endomychides) d'Angola. Revue Suisse de Zoology 44: 483-489. 